Methamphetamine health and justice

\title{
Methamphetamine use, health and criminal justice system outcomes: a systematic review
}

Craig Cumming ${ }^{1}$, Stuart A Kinner ${ }^{2,3,4,5,6}$, Rebecca McKetin ${ }^{7}$, Ian Li ${ }^{8}$, David Preen ${ }^{1}$

1. Centre for Health Services Research, School of Population and Global Health, University of Western Australia, Perth, Australia

2. Centre for Adolescent Health, Murdoch Children's Research Institute, Melbourne, Australia

3. Melbourne School of Population and Global Health, The University of Melbourne, Melbourne, Australia

4. Griffith Criminology Institute, Griffith University, Brisbane, Australia

5. School of Public Health and Preventive Medicine, Monash University, Melbourne, Australia

6. Mater Research Institute-UQ, University of Queensland, Brisbane, Australia

7. National Drug and Alcohol Research Centre, UNSW Sydney, Sydney, Australia

8. School of Population and Global Health, University of Western Australia, Perth, Australia

Craig Cumming LLB (Hons), PhD Candidate, Stuart A Kinner PhD, NHMRC Senior Research Fellow, Rebecca McKetin PhD, Associate Professor, Ian Li PhD, Assistant Professor and Senior Lecturer, David Preen PhD, Chair in Public Health.

Corresponding Author:

Mr Craig Cumming, Centre for Health Services Research, School of Population and Global Health, University of Western Australia, M431, 35 Stirling Highway, Crawley, WA 6009, Australia. T: +61 8 6488 1298; F: +61 86488 1188; Email: craig.cumming@uwa.edu.au

This is the author manuscript accepted for publication and has undergone full peer review but has not been through the copyediting, typesetting, pagination and proofreading process, which may lead to differences between this version and the Version of Record. Please cite this article as doi: 10.1111/dar.13062

This article is protected by copyright. All rights reserved. 


\section{Abstract}

Issues. Methamphetamine use is a problem for health and criminal justice systems (CJS) worldwide. Methamphetamine is used at higher rates in CJS-involved populations than the general community. This systematic review synthesises the evidence for health and CJS outcomes post-CJS contact for people reporting pre-CJS methamphetamine use.

Approach. Academic databases were searched to identify peer-reviewed original studies using a longitudinal design that investigated associations between pre-CJS methamphetamine use and health and criminal justice outcomes after CJS contact. Identified studies were screened in two stages; title and abstract, then full-text. Data from the included studies were extracted and analysed. Results are reported in line with the PRISMA statement.

Key Findings. Nine studies met the inclusion criteria; five investigated health and four investigated CJS outcomes. Pre-CJS methamphetamine use was associated with subsequent hospitalisation for drug-induced psychosis, increased risk of recidivism and higher crime costs after CJS contact. Pre-CJS methamphetamine use was not associated with subsequent hospitalisation for non-drug induced psychosis or post-release mortality.

Implications. Current evidence suggests that pre-CJS contact methamphetamine use increases the risk of subsequent drug-induced psychosis and recidivism. There is a need for more longitudinal research that measures mediators and moderators of health and criminal justice outcomes after CJS contact, to inform targeted prevention.

Conclusion. Methamphetamine use is a major problem that is contributing to serious mental illness and recidivism among CJS-involved populations. Prioritising treatment during CJS contact is recommended. Further research to identify key opportunities during health service and CJS contact for intervention is needed.

Key words: substance-related disorders, methamphetamine, mental disorders, risk, criminal justice 


\section{Introduction}

Methamphetamine use is posing an increasing problem in many countries [1], due in part to the severe psychiatric [2] and physical health problems [3, 4] associated with its use, as well as the social [5] and criminal justice system (CJS) impact [6]. Justice costs make up a substantial proportion of the overall economic costs attributed to methamphetamine use $[7,8]$. Australian research suggests that recent increases in methamphetamine availability have been associated with a commensurate increase in regular use and associated harms [6]. This may explain the doubling of the rate of deaths associated with methamphetamine use in Australia between 2009 and 2015 [3]. There is also evidence of a dose-response relationship between methamphetamine use and the use of psychiatric hospitals and emergency departments in Australia attributable to methamphetamine use [9]. In the United States, amphetamine-related hospitalisations increased from 55,447 to 206,180 per year between 2008 and 2015, at an estimated cost of US\$2.17 billion for 2015 hospitalisations alone [10]. Amphetamine-related hospitalisations are also associated with higher in-hospital mortality, and greater length of stay, compared with non-amphetamine-related hospitalisations [10]. There have also been recent increases in methamphetamine use in lower-income country settings including South Africa [11] and Iran [12], which pose ongoing public health concerns such as increased risk of HIV transmission [13]. These findings illustrate the substantial burden that methamphetamine use is currently having on health systems across different countries.

The impact of methamphetamine use is arguably most pronounced in the CJS. Urinalysis testing on arrestees detained at police watch-houses across Australia in 2016 found that 53\% tested positive for amphetamine, the most prevalent of any illicit drug [14]. This is consistent with an Australian report estimating that $50 \%$ of prison entrants had used methamphetamine in the 12 months prior to prison - again, the highest prevalence of any illicit drug [15]. These results indicate a substantially higher prevalence of methamphetamine use in Australian justice-involved populations compared with an estimated $1.4 \%$ of the general Australian population [16]. These results are mirrored in the United States, where in Sacramento, California, $50 \%$ of a sample of arrestees tested positive for methamphetamine, followed by $16 \%$ in Denver, Colorado [17], compared with a 2014 estimate of $0.2 \%$ of the general United States population over 12 years of age who reported using methamphetamine in the past month [18].

People released from prison are at an increased risk of poor health outcomes including violent [19] and drug-related $[20,21]$ death, suicide [22, 23], non-fatal overdose [24] and hospitalisation for health problems including mental illness, skin disease, injury and poisoning [25]. Recent Australian trends show that increased methamphetamine use is associated with an increase in hospital admissions for drug psychosis, and increases in arrests of methamphetamine users for methamphetamine dealing and possession [6]. What appears unclear from the current evidence is how methamphetamine use by people who go on to have contact with the CJS may be associated with poor health and justice outcomes after contact with the CJS. Given the increasing harms and costs associated with methamphetamine use generally, and the high prevalence of methamphetamine use in people who have contact with the CJS, a review of the evidence regarding 
the relationship between prior methamphetamine use and post-CJS contact health and justice outcomes is warranted.

The main aim of this systematic review [26] is to identify and synthesise the existing evidence on health, health service and criminal justice outcomes for people who: (i) had contact with the CJS (including being arrested by police, incarcerated or being subject to a community-based supervision order); and (ii) who had used methamphetamine prior to the index episode of contact with the CJS considered by the study. Because this review focussed on outcomes after contact with the CJS, evidence included was limited to longitudinal studies where temporal inferences were possible.

\section{Methods}

\section{Information sources}

We systematically searched Scopus, Web of Science, Psyclnfo and PubMed for the period beginning at inception and ending on 28 June 2018.

\section{Search strategy}

Each database was searched by author CC using the terms outlined in Table 1.

\section{INSERT TABLE 1}

Author CC conducted the search and performed a two-stage screening process to identify studies that met the inclusion criteria. Firstly, all records were screened using title and abstract, then studies not excluded during this first stage were screened using their full text. Additionally, the reference lists of included studies were searched for potentially eligible studies.

\section{Study selection}

The criteria for inclusion of publications in the review were as follows:

1. Original research (both quantitative and qualitative);

2. Involving human participants who have had contact with the CJS;

3. Incorporating a longitudinal study design;

4. Written in English;

5. Published in a peer-reviewed journal;

6. Were deemed to be methodologically sound and suitable for inclusion using the Joanna Briggs Critical Appraisal Checklist for cohort studies [27];

7. Reporting on at least one of the following outcomes after contact with the CJS:

a. health or health service use outcomes;

b. criminal justice outcomes; including
i. Police arrests;
ii. Incarceration; and
iii. Self-reported criminal activity; 
8. Where methamphetamine use prior to the index episode of criminal justice contact was considered as a potentially associated exposure.

There were no restrictions placed on the nature of the index episode of contact with the CJS, meaning that studies involving participants who had contact that did not involve incarceration were eligible for inclusion. Studies that compared participants with and without CJS contact were also considered.

Author CC conducted the search and screening of studies for potential inclusion, and recorded the results of each step for reporting pursuant to the PRISMA statement [28].

\section{Data extraction}

Using a structured data extraction template developed for this study, the following data were extracted: author(s); publication date; setting; study design; study measures; type of methamphetamine exposure measured (Table 2); study group/population; study period (if available); mean/median age (if reported); percentage of female participants; outcomes investigated; relevant socio-environmental factors of interest; and significant relationships reported between factors of interest and outcomes (Table 3).

INSERT TABLES 2 and 3

\section{Risk of bias (quality) assessment}

The Joanna Briggs Critical Appraisal Checklist for cohort studies [27] was used by author CC to assess the quality of identified studies, and to determine their suitability for inclusion in the review. The process of determining the quality assessment ratings for each item for each study is described in more detail in the supporting information.

\section{Data synthesis and analysis}

The health, health service and justice outcomes investigated by the included studies were extracted using the extraction template mentioned above, and categorised as either health or justice outcomes.

\section{Results}

\section{Search results and study selection}

Figure 1 shows a flow diagram of the literature search and screening process and results. The initial search identified 6334 records. After the removal of 2520 duplicates, 3814 studies were screened on title and abstract. Following title and abstract screening, the full text of 86 records was screened, resulting in nine publications meeting the inclusion criteria [19, 29, 31-33, 36-39]. The results of the quality assessment are included in the supporting information available online (Table S1). Of the 
studies excluded during title and abstract screening, 110 were review articles. None of these reviews had focussed on the specific aim being investigated by this review.

\section{INSERT FIGURE 1}

\section{Quality assessment}

The quality of the included studies was high overall with a mean score of $89 \%$ (range: $70-100 \%$ ), with all studies deemed to be of sufficient quality for inclusion. The items that the smallest proportion of studies were endorsed for were groups/participants being free of the outcome at the start of the study/time of exposure (75\%) and strategies used to address incomplete follow up (67\%). It should be noted however that incomplete follow up was only an issue for three of the studies [29, 31, 33]. All studies were endorsed for recruiting study groups from the same population, measuring exposure in a valid/reliable way, identifying confounding factors and measuring outcomes in a valid/reliable way.

\section{Study setting and design}

The nine included studies were set in Sweden [19, 36-39], the United States [29, 32], Taiwan [31] and Canada [33]. Six of the included studies solely involved participants who were in custodial settings at some stage during the study period [29, 31, 32, 37-39]. Two of the studies involved participants who were either in custody or subject to community corrections orders at some stage during the study period $[19,36]$. One study involved participants who were recruited in the community and who may or may not have reported prior and/or subsequent contact with the CJS (incarceration, community-based supervision or arrest) or criminal activity [33].

Follow-up times varied by study; four studies did not report a fixed follow-up time due to participants entering or exiting the cohort at different times [19, 33, 36, 38]. The shortest fixed follow-up time reported was nine months [29] and the longest was five years [31].

\section{Study participants}

Participants across all but one study [33] were adults with a history of contact with the CJS. Enns et al [33] was the only included study that involved some participants who did not report prior contact with the CJS. Sample sizes ranged from 794 [31] to 6217 [39], and all but one study [31] included both male and female participants, with $43 \%$ being the highest proportion of female participants reported [32]. Four studies [29, 31, 32, 36] included a no-methamphetamine use comparison group, three $[19,33,38]$ included only methamphetamine users, one study used a comparison group that reported no current drug problem, described by the authors as a "less severe and perhaps terminated substance use" group [39], and one study compared death rates of methamphetamine using participants with national mortality data [37]. 


\section{Measures and data collection}

All studies used a survey tool to collect baseline data. The tool most commonly used was the Addiction Severity Index (ASI) [40], with different versions of the ASI used across six studies [19, 32, 36-39]. All but one included study [29] used administrative records to measure post CJS contact outcomes.

\section{Outcomes investigated across studies}

Recidivism was the most common outcome investigated across included studies, with three studies focusing on this [31, 32, 36]. Two studies investigated either mortality [19, 37] or hospitalisation for psychosis [38,39], which were the next most common outcomes investigated. Of the other studies, Cartier et al [29] investigated whether elevated HIV risk behaviours persisted from the period before through to the period after incarceration, and Enns et al [33] investigated monthly crime costs.

\section{Methamphetamine-related findings}

The methamphetamine-related findings were grouped into two categories, health and criminal justice. Five of the included studies reported on health outcomes [19, 29, 37-39] and four reported on criminal justice-related outcomes [31-33, 36]. None of the included studies reported on both health and criminal justice outcomes. Findings of no association were also included here.

Among the health-focused studies, Rognli et al [39] found that reporting an amphetamine problem at baseline (i.e. during index CJS contact) was positively associated with subsequent hospitalisation for drug-induced psychosis [odds ratio (OR) 3.61; 95\% confidence interval (Cl) 1.25-10.40]; however, no association was found for primary psychosis. Rognli et al [38] found no evidence of an association between hospitalisation for psychosis and three measures of patterns of amphetamine use; age of onset, number of years of use and days of use in the past month, measured at baseline.

Similarly, Cartier et al [29] found no association between methamphetamine use reported at baseline and increased odds of unsafe sex, unsafe injecting or concurrent unsafe sex and injecting practices at nine-month follow-up. This study did, however, find that baseline methamphetamine use was associated with methamphetamine use at post-sentence follow-up, which in turn was associated with greater odds of risky sexual behaviour and risky injecting at follow-up [29]. Ericsson et al [19] found a small but statistically significant negative association between a greater number of days of amphetamine use in the past 30 days and risk of death in their study sample (hazard ratio 0.96; $95 \% \mathrm{Cl} 0.93-0.98$ ). They also found a similarly small but statistically significant positive association between greater number of days of sedative use in the past 30 days and risk of death (hazard ratio 1.03; 95\% $\mathrm{Cl} 1.00-1.06$ ) [19]. Hakansson and Berglund [37] found no association between lifetime amphetamine use for a period of at least six months and post-release death.

With respect to criminal justice outcomes, Håkansson and Berglund [36] reported that injection use of methamphetamine both alone $(\mathrm{OR} 1.95 ; 95 \% \mathrm{Cl} 1.74-2.18)$ and concurrently with heroin (OR 2.08; $95 \% \mathrm{Cl}$ 1.81-2.40), and non-injection use of methamphetamine both alone (OR 1.28; $95 \% \mathrm{Cl} 1.13-$ 1.45) and concurrently with heroin (OR 1.43; 95\% $\mathrm{Cl}$ 1.07-1.93), were associated with increased risk of recidivism compared with those who reported no use of methamphetamine or heroin. Enns et al [33] found that there were higher monthly crime-related costs associated with daily (CAD\$5845) and 
non-daily (CAD\$5723) methamphetamine use when compared to no use, as well as for daily (CAD\$8893) and non-daily (CAD\$5449) poly-stimulant use involving methamphetamine compared to no poly-stimulant use. They found that route of methamphetamine administration was not a significant factor in crime-related costs, with injection of methamphetamine not associated with significantly higher costs compared to non-injection use [33]. Chiang et al [31] found that the odds of recidivism were greater for participants testing positive for methamphetamine at intake compared to those testing negative (OR 1.6; $95 \% \mathrm{Cl} 1.2-2.1$ ). Chiang et al [31] also found that methamphetamine use in their all-male sample was associated with lower rates of recidivism and longer survival time to recidivism when compared to heroin use. Similarly, Du et al [32] found that for female participants, recidivism was less likely to occur for participants who used methamphetamine when compared to those who used cocaine.

\section{Discussion}

We found few longitudinal studies that investigate outcomes associated with methamphetamine use in CJS populations. The extant evidence suggests that people who use methamphetamine prior to CJS contact are at increased risk of subsequent contact compared to their counterparts who have not used methamphetamine $[31,36,41]$. However the risk recidivism of was lower for pre-CJS methamphetamine users when compared to those who used heroin [31] or cocaine [32] during the same period. The evidence around associations between pre-CJS methamphetamine use and poor health outcomes was mixed. One study found an association between pre-CJS methamphetamine use and subsequent hospitalisation for drug-induced psychosis [39], however no such associations were found for hospitalisation for non-drug induced psychosis [38] or mortality [19] (in contrast to heroin [37]).

Previous research into drug-related health outcomes after contact with the CJS has focussed on outcomes more commonly associated with opioid use, such as death $[21,42,43]$ and non-fatal drug overdose $[24,44]$. The results from the relatively small body of literature in this space suggest that methamphetamine use poses different types of health challenges to opioid use post-CJS contact [21, $29]$, with psychosis being a key area of concern $[38,39]$. This has implications for transitional planning for criminal justice agencies: rather than overdose prevention strategies, people with a history of methamphetamine use may require more tailored mental health support.

The included studies provide evidence of a positive association between methamphetamine use and both crime costs [33] and recidivism [36]. These findings echo elsewhere in the literature [7, 33, 36, 42], and highlight the potential for interventions that reduce methamphetamine use and related harm after CJS contact to be cost-effective, as well as the importance of health economic evaluation of such interventions. Given the relationship between methamphetamine use and crime, implementing effective psychosocial interventions aimed at reducing or ceasing methamphetamine use $[46,47]$ should be considered in CJS-involved populations.

\section{Strengths and limitations of the included studies}

As reflected in the results of the quality assessment, the key strengths of the included studies generally lay in their design and data sources. All but one study [33] drew their participants from 
comprehensive administrative justice datasets. These datasets included methamphetamine exposure data, and routinely collected outcome data for appropriate follow up periods. Enns et al [33] used an established survey tool to collect both exposure and outcome data, and utilised a wide range of costing data to comprehensively estimate costs from a societal perspective. Follow-up was generally good across the studies, with exceptions where loss to follow up was either mentioned but not explored further $[29,33]$, or described in detail but not accounted for in the statistical methods used [31].

One of the main limitations across studies is that they are observational, so no causal inferences between methamphetamine use and the outcomes of interest could be made. Relatedly, methamphetamine use was only measured at one time point across studies, usually a considerable time prior to the outcomes being investigated. This limits the temporal connection between methamphetamine use and those outcomes, and raises the possibility that other unmeasured exposures may have contributed to the outcomes reported.

The small number of health-focused studies and their narrow scope (limited to HIV risk behaviours [29], mortality [19, 37] and psychosis [38, 39]), made it difficult to compare outcomes across studies. Importantly, most of the adverse health outcomes associated with methamphetamine use (including depression, cardio-vascular disease, methamphetamine dependence and suicide $[4,48])$, were not investigated by the included studies. This gap in the literature needs to be addressed in light of the high prevalence of methamphetamine use among CJS populations [14, 15, 17], and the impact that this has on health and CJS services [6, 8-10].

\section{Strengths and limitations of this review}

The main strength of this systematic review was the comprehensive search strategy, which was informed by the PRISMA statement [28]. An additional strength was the quality assessment conducted. One limitation of the study is the exclusion of grey literature and non-English literature. However, no non-English literature was retrieved during the literature search, and grey literature was considered in the background research done for the review; none of which would have met the eligibility criteria for inclusion. There is a possibility that these exclusion criteria may have resulted in relevant literature not being included in the review. A further limitation is that screening of the fulltext of articles was not performed by an independent assessor; this may have resulted in studies being screened as ineligible that may have been picked up by a second assessor.

\section{Implications for future research}

To address the issues around the temporal connection between methamphetamine exposure and outcomes, studies involving people who have been incarcerated should be designed to investigate exposures and outcomes at multiple time points after baseline measures are administered. This would enable further investigation of time-varying risk factors that may impact different stages of a person's reintegration into the community. This would also assist researchers to investigate possible effect mediators and moderators.

Given that people who have contact with the CJS are inherently vulnerable and often difficult to engage with outside of a custodial setting, a program of systematic data collection should be 
considered in prison systems to support further high-quality research in this important area. One example of this is the systematic use of the ASI in the Swedish correctional system, which enabled five of the studies in this review $[19,36-39]$ to be conducted.

There is also a need for more research to understand the mechanisms that result in poor health and criminal justice outcomes for people who use methamphetamine. With much of the existing literature focused on very specific health or justice outcomes, future research should consider broader contextual health and social factors (e.g. education, employment, income, housing, domestic violence and the role of families) which may impact on recidivism. Such research would provide valuable findings for policy makers and practitioners who are responsible for addressing the often-complex needs of people who go to prison.

\section{Conclusion}

There is some evidence that pre-CJS contact methamphetamine use is associated with subsequent recidivism, crime-related costs and drug-induced psychosis, with no current evidence of an association with non-drug-induced psychosis or mortality. This highlights the need for interventions that reduce methamphetamine use in the CJS setting to prevent the associated poor outcomes. Methamphetamine use in is associated with different adverse health outcomes than the more established harms associated with opioid use. Further research is needed to better understand the broader range of harms associated with methamphetamine use in the CJS, and the context in which these harms occur. 


\section{AUTHOR DISCLOSURES:}

\section{Role of Funding Source}

CC is supported by an Australian Government Research Training Program Scholarship (PhD). The funding source mentioned herein had no additional role in the research design; data collection, analysis or interpretation; the writing of the manuscript; or the decision to submit the article for publication.

\section{Conflict of Interest}

Apart from the funding resources disclosed in the acknowledgements section, all authors declare no conflicts of interest. 


\section{References}

[1] Stoneberg DM, Shukla RK, Magness MB. Global methamphetamine trends: an evolving problem. Int Crim Justice Rev 2018;28:136-61.

[2] McKetin R, Lubman DI, Baker AL, Dawe S, Ali RL. Dose-related psychotic symptoms in chronic methamphetamine users: evidence from a prospective longitudinal study. JAMA Psychiatry 2013;70:319-24.

[3] Darke S, Kaye S, Duflou J. Rates, characteristics and circumstances of methamphetamine-related death in Australia: a national 7-year study. Addiction 2017;112:2191-201.

[4] Darke S, Darke S, Kaye S, Darke S, Kaye S, McKetin R, Darke S, Kaye S, McKetin R, Duflou J. Major physical and psychological harms of methamphetamine use. Drug Alcohol Rev 2008;27:253-62.

[5] McKetin R, Lubman DI, Najman JM, Dawe S, Butterworth P, Baker AL. Does methamphetamine use increase violent behaviour? Evidence from a prospective longitudinal study. Addiction 2014;109:798-806.

[6] Degenhardt L, Sara G, McKetin R, Roxburgh A, Dobbins T, Farrell M, Burns L, Hall WD. Crystalline methamphetamine use and methamphetamine-related harms in Australia. Drug Alcohol Rev 2017;36:160-70.

[7] Tait RJ, Whetton S, Shanahan M, Cartwright K, Ferrante A, Gray D, Kaye S, McKetin R, Pidd K, Ritter A. Quantifying the societal cost of methamphetamine use to Australia. Int J Drug Policy 2018;62:30-6.

[8] Nicosia N, Pacula RL, Kilmer B, Lundberg R, Chiesa J. The economic cost of methamphetamine use in the United States, 2005. RAND HEALTH SANTA MONICA CA; 2009.

[9] McKetin R, Degenhardt L, Shanahan M, Baker AL, Lee NK, Lubman DI. Health service utilisation attributable to methamphetamine use in Australia: Patterns, predictors and national impact. Drug Alcohol Rev 2018;37:196-204.

[10] Winkelman TNA, Admon LK, Jennings L, Shippee ND, Richardson CR, Bart G. Evaluation of amphetamine-related hospitalizations and associated clinical outcomes and costs in the United States. JAMA Netw Open 2018;1:e183758.

[11] Weybright EH, Caldwell LL, Wegner L, Smith E, Jacobs JJ. The state of methamphetamine ('tik') use among youth in the Western Cape, South Africa. S Afr Med J 2016;106:1125-8.

[12] Alammehrjerdi Z, Ezard N, Dolan K. Methamphetamine dependence in methadone treatment services in Iran: the first literature review of a new health concern. Asian J Psychiatr 2018;31:49-55.

[13] Meade CS, Lion RR, Cordero DM, Watt MH, Joska JA, Gouse H, Burnhams W. HIV risk behavior among methamphetamine users entering substance abuse treatment in cape town, South Africa. AIDS Behav 2016;20:2387-97.

[14] Patterson E, Sullivan T, Ticehurst A, Bricknell S. Drug use monitoring in Australia: 2015 and 2016 report on drug use among police detainees. Canberra: Australian Institute of Criminology; 2018. Report No.: Statistical Reports No. 4 Contract No.: Statistical Reports No. 4.

[15] Australian Institute of Health and Welfare. The health of Australia's prisoners 2015. Canberra: AlHW; 2015. Report No.: Cat. no. PHE 207.

[16] Australian Institute of Health and Welfare. National Drug Strategy Household Survey 2016: detailed findings. Canberra: AlHW; 2017. Contract No.: PHE214. 
[17] Hunt D, Chapman M, Jalbert S, Kling R, Almozlino Y, Rhodes W, Flygare C, Neary K, Nobo C. 2013 Annual Report: Arrestee Drug Abuse Monitroing Program II. Washington DC: Office of National Drug Control Policy; 2014.

[18] Center for Behavioral Statistics and Quality. Behavioral health trends in the United States: results from the 2014 National Survey on Drug Use and Health. 2015. Contract No.: HHS Publication No. SMA 15-4927, NSDUH Series H-50.

[19] Ericsson E, Bradvik L, Hakansson A. Mortality, causes of death and risk factors for death among primary amphetamine users in the Swedish criminal justice system. Subst Use Misuse 2014;49:262-9.

[20] Merrall ELC, Kariminia A, Binswanger IA, Hobbs MS, Farrell M, Marsden J, Hutchinson SJ, Bird SM. Meta-analysis of drug-related deaths soon after release from prison. Addiction 2010;105:1545-54.

[21] Binswanger IA, Blatchford PJ, Mueller SR, Stern MF. Mortality after prison release: opioid overdose and other causes of death, risk factors, and time trends from 1999 to 2009. Ann Intern Med 2013;159:592-600.

[22] Spittal MJ, Forsyth S, Pirkis J, Alati R, Kinner SA. Suicide in adults released from prison in Queensland, Australia: a cohort study. J Epidemiol Community Health 2014;68:993-8. [23] Borschmann R, Young JT, Moran P, Spittal MJ, Kinner SA. Identifying and reducing self-harm among people exposed to the CJS: A public health opportunity. Lancet Public Health (In press).

[24] Winter RJ, Stoové M, Degenhardt L, Hellard ME, Spelman T, Jenkinson R, McCarthy DR, Kinner SA. Incidence and predictors of non-fatal drug overdose after release from prison among people who inject drugs in Queensland, Australia. Drug Alcohol Depend 2015;153:43-9.

[25] Hobbs M, Krazlan K, Ridout S, Mai Q, Knuiman M, Chapman R. Mortality and morbidity in prisoners after release from prison in Western Australia 1995-2003. Trends and Issues in Crime and Criminal Justice. 2006.

[26] Grant MJ, Booth A. A typology of reviews: an analysis of 14 review types and associated methodologies. Health Info Libr J 2009;26:91-108.

[27] The Joanna Briggs Institute. Critical Appraisal tools for use in Systematic Reviews: Checklist for Cohort Studies 2017 [Available from:

http://joannabriggs.org/assets/docs/critical-appraisal-tools/JBI Critical AppraisalChecklist for Cohort Studies2017.pdf.

[28] Moher D, Liberati A, Tetzlaff J, Altman DG. Preferred reporting items for systematic reviews and meta-analyses: the PRISMA statement. Ann Intern Med 2009;151:264-9.

[29] Cartier JJ, Greenwell L, Prendergast ML. The persistence of HIV risk behaviors among methamphetamine-using offenders. J Psychoactive Drugs 2008;40:437-46.

[30] Simpson DO, Knight,K. TCU Data Collection Forms for Correctional Residential Treatment. Fort Worth: Texas Christian University, Institute of Behavioral Research;. 1998. Available at: https://ibr.tcu.edu/forms/forms-archives/cj-forms-correctional-residentialtreatment/

[31] Chiang SC, Chan HY, Chen CH, Sun HJ, Chang HJ, Chen WJ, Lin SK, Chen CK. Recidivism among male subjects incarcerated for illicit drug use in Taiwan. Psychiatry Clin Neurosci 2006;60:444-51.

[32] Du J, Huang D, Zhao M, Hser YI. Drug-abusing offenders with co-morbid mental disorders: gender differences in problem severity, treatment participation, and recidivism. Biomed Environ Sci 2013;26:32-9. 
[33] Enns B, Krebs E, DeBeck K, Hayashi K, Milloy MJ, Richardson L, Wood E, Nosyk B. The costs of crime associated with stimulant use in a Canadian setting. Drug Alcohol Depend 2017;180:304-10.

[34] Radloff LS. The CES-D scale: A self-report depression scale for research in the general population. Appl Psychol Meas 1977;1:385-401.

[35] Öberg D, Zingmark D, Sallmén B. ASI-X v1.1; 1999 [Available from:

https://www.kean.edu/ roneilfi/ASI.pdf]

[36] Håkansson A, Berglund M. Risk factors for criminal recidivism-a prospective follow-up study in prisoners with substance abuse. BMC Psychiatry 2012;12:111.

[37] Hakansson A, Berglund M. All-cause mortality in criminal justice clients with substance use problems-A prospective follow-up study. Drug Alcohol Depend 2013;132:499-504.

[38] Rognli EB, Håkansson A, Berge J, Bramness JG. Does the pattern of amphetamine use prior to incarceration predict later psychosis?-A longitudinal study of amphetamine users in the Swedish criminal justice system. Drug Alcohol Depend 2014;143:219-24.

[39] Rognli EB, Berge J, Håkansson A, Bramness JG. Long-term risk factors for substanceinduced and primary psychosis after release from prison. A longitudinal study of substance users. Schizophr Res 2015;168:185-90.

[40] McLellan AT, Luborsky L, Woody GE, O'Brien CP. An improved diagnostic evaluation instrument for substance abuse patients: the Addiction Severity Index. J Nerv Ment Dis 1980;168:26-33.

[41] Cartier J, Farabee D, Prendergast ML. Methamphetamine use, self-reported violent crime, and recidivism among offenders in California who abuse substances. J Interpers Violence 2006;21:435-45.

[42] Leach D, Oliver P. Drug-related death following release from prison: a brief review of the literature with recommendations for practice. Curr Drug Abuse Rev 2011;4:292-7.

[43] Andrews JY, Kinner SA. Understanding drug-related mortality in released prisoners: a review of national coronial records. BMC Public Health 2012;12:270.

[44] Håkansson A, Schlyter F, Berglund M. Factors associated with history of non-fatal overdose among opioid users in the Swedish criminal justice system. Drug Alcohol Depend 2008;94:48-55.

[45] Goldsmid S, Willis M. Methamphetamine use and acquisitive crime: Evidence of a relationship. Trends and Issues in Crime and Criminal Justice no. 516. 2016; Canberra: Australian Institute of Criminology. https://aic.gov.au/publications/tandi/tandi516.

[46] McKetin R, Kothe A, Baker AL, Lee NK, Ross J, Lubman DI. Predicting abstinence from methamphetamine use after residential rehabilitation: Findings from the Methamphetamine Treatment Evaluation Study. Drug Alcohol Rev 2018;37:70-8.

[47] McKetin R, Dunlop AJ, Holland RM, Sutherland RA, Baker AL, Salmon AM, Hudson SL. Treatment outcomes for methamphetamine users receiving outpatient counselling from the Stimulant Treatment Program in Australia. Drug Alcohol Rev 2013;32:80-7.

[48] Akindipe T, Wilson D, Stein DJ. Psychiatric disorders in individuals with methamphetamine dependence: prevalence and risk factors. Metab Brain Dis 2014;29:3517. 
Table 1. Search terms

\begin{tabular}{|l|l|l|}
\hline \multicolumn{1}{|c|}{ Terms A } & \multicolumn{1}{|c|}{ Terms B } \\
\hline ATS & & legal \\
Amphetamine type stimulant\$ & prison\$ \\
\$amphetamine & justice \\
metamfetamine & police \\
\$amphetamine hydrochloride & and & incarcerat\$ \\
n-methylamphetamine & detention \\
stimulant\$ & detain\$ \\
& & arrest\$ \\
& & crim\$ \\
& correcti\$ \\
& court \\
\hline
\end{tabular}

This article is protected by copyright. All rights reserved. 
Table 2. Study setting and design

\begin{tabular}{|c|c|c|c|c|c|c|}
\hline Author, date [ref] & Country & Setting & Study design & Measures used & $\begin{array}{c}\text { Type of } \\
\text { methamphetamine } \\
\text { exposure reported }\end{array}$ & $\begin{array}{c}\text { Socio-environmenal factor(s) } \\
\text { of interest }\end{array}$ \\
\hline Cartier, 2008 [29] & USA & $\begin{array}{l}\text { Prisons in Colorado, } \\
\text { Connecticut, Kentucky } \\
\text { and Oregon and the } \\
\text { community }\end{array}$ & $\begin{array}{l}\text { Prospective } \\
\text { cohort }\end{array}$ & $\begin{array}{l}\text { Exposure: } \\
\text { - Department of Criminal } \\
\text { Justice-Therapeutic } \\
\text { Community Intake Form } \\
\text { (Simpson \& Knight 1998) } \\
\text { [30] } \\
\text { Outcome: } \\
\text { - Department of Criminal } \\
\text { Justice-Therapeutic } \\
\text { Community Intake Form } \\
\text { (Simpson \& Knight 1998) } \\
\text { [30] }\end{array}$ & Any use in past 30 days & $\begin{array}{l}\text { Age } \\
\text { Race/ethnicity } \\
\text { Marital status } \\
\text { Living with partner/alone } \\
\text { Education level } \\
\text { Employment (past six months) } \\
\text { Methamphetamine use } \\
\text { Substance abuse treatment } \\
\text { episodes }\end{array}$ \\
\hline
\end{tabular}

This article is protected by copyright. All rights reserved. 
Methamphetamine health and justice

\begin{tabular}{|c|c|c|c|c|c|c|}
\hline Chiang, 2006 [31] & Taiwan & $\begin{array}{l}\text { Acute detoxification } \\
\text { unit with detention } \\
\text { centre in Taiwan }\end{array}$ & $\begin{array}{l}\text { Retrospective } \\
\text { Cohort }\end{array}$ & $\begin{array}{l}\text { Exposure: } \\
\text { - Urinalysis } \\
\text { - Semi-structured } \\
\text { psychiatrist-administered } \\
\text { interview to asses AOD use } \\
\text { Outcome: } \\
\text { - Administrative } \\
\text { incarceration data from } \\
\text { the Taiwan Ministry of } \\
\text { Justice }\end{array}$ & $\begin{array}{l}\text { Lifetime abuse or } \\
\text { dependence } \\
\text { Positive urinalysis test at } \\
\text { intake }\end{array}$ & $\begin{array}{l}\text { Methamphetamine use } \\
\text { Heroin use } \\
\text { Age of first drug use } \\
\text { Family relationship status }\end{array}$ \\
\hline Du, 2013 [32] & USA & $\begin{array}{l}\text { California's } \\
\text { Proposition } 36 \text { Mental } \\
\text { Health Service for } \\
\text { people who had } \\
\text { offended }\end{array}$ & $\begin{array}{l}\text { Prospective and } \\
\text { retrospective } \\
\text { Cohort }\end{array}$ & $\begin{array}{l}\text { Exposure: } \\
\text { - ASI } \\
\text { - Mental Health Records } \\
\text { Outcome: } \\
\text { - Administrative arrest } \\
\text { data from the California } \\
\text { Department of Justice }\end{array}$ & Addiction severity & $\begin{array}{l}\text { Methamphetamine use } \\
\text { Other AOD use } \\
\text { Gender } \\
\text { Race } \\
\text { Marital Status } \\
\text { Treatment modality } \\
\text { Treatment retention } \\
\text { Mental Illness (anxiety, } \\
\text { depression, psychotic disorder) }\end{array}$ \\
\hline
\end{tabular}

This article is protected by copyright. All rights reserved. 


\begin{tabular}{|c|c|c|c|c|c|c|}
\hline Enns, 2017 [33] & Canada & $\begin{array}{l}\text { Community drug using } \\
\text { groups }\end{array}$ & $\begin{array}{l}\text { Retrospective } \\
\text { Cohort }\end{array}$ & $\begin{array}{l}\text { Exposure: } \\
\text { - Structured survey } \\
\text { incorporating CES-D scale } \\
\text { (Radloff 1977) [34] } \\
\text { Outcome: } \\
\text { - Structured survey } \\
\text { incorporating CES-D scale } \\
\text { (Radloff 1977) [34] } \\
\text { - Administrative data on } \\
\text { crime incident costs } \\
\text { derived from Vancouver } \\
\text { Police Department } \\
\text { operating budget }\end{array}$ & $\begin{array}{l}\text { Daily or non-daily use in } \\
\text { previous } 6 \text { months }\end{array}$ & $\begin{array}{l}\text { Stimulant use } \\
\text { (methamphetamine, } \\
\text { powdered cocaine, crack- } \\
\text { cocaine, polystimulant) } \\
\text { Mode of use } \\
\text { Frequency of use }\end{array}$ \\
\hline Ericsson, 2014 [19] & Sweden & $\begin{array}{l}\text { Swedish prisons and } \\
\text { community } \\
\text { corrections }\end{array}$ & $\begin{array}{l}\text { Prospective } \\
\text { Cohort }\end{array}$ & $\begin{array}{l}\text { Exposure: } \\
\text { - ASI-X (Oberg 1999) [35] } \\
\text { Outcome: } \\
\text { - Administrative mortality } \\
\text { data from the Swedish } \\
\text { National Causes of Death } \\
\text { Register }\end{array}$ & $\begin{array}{l}\text { Days of use in previous } 30 \\
\text { days }\end{array}$ & $\begin{array}{l}\text { Days of opioid, sedative, } \\
\text { cocaine, amphetamine, and } \\
\text { cannabis use } \\
\text { History of injecting } \\
\text { Hepatitis C } \\
\text { Prior psychiatric medication } \\
\text { use } \\
\text { Previous suicide attempt } \\
\text { Previous suicidal ideation } \\
\text { Previous cognitive symptoms } \\
\text { Age at intake }\end{array}$ \\
\hline
\end{tabular}




\begin{tabular}{|c|c|c|c|c|c|c|}
\hline Håkansson, 2012 [36] & Sweden & $\begin{array}{l}\text { Swedish prisons and } \\
\text { community } \\
\text { corrections }\end{array}$ & $\begin{array}{l}\text { Prospective } \\
\text { cohort }\end{array}$ & $\begin{array}{l}\text { Exposure: } \\
\text { - ASI } \\
\text { Outcome: } \\
\text { - Administrative justice } \\
\text { data from the Swedish } \\
\text { Criminal Justice Registry }\end{array}$ & $\begin{array}{l}\text { Lifetime history of Injecting } \\
\text { use for greater than 6- } \\
\text { month period } \\
\text { Lifetime history of non- } \\
\text { Injecting use for greater } \\
\text { than 6-month period }\end{array}$ & $\begin{array}{l}\text { Age } \\
\text { Gender } \\
\text { Homelessness in last } 30 \text { days } \\
\text { Lifetime history of psychiatric } \\
\text { problems } \\
\text { Lifetime history of substance } \\
\text { use } \\
\text { Number of substance types } \\
\text { used in last } 30 \text { days } \\
\text { Duration of index sentence } \\
\text { Main crime in index verdict }\end{array}$ \\
\hline Håkansson, 2013 [37] & Sweden & Swedish prisons & $\begin{array}{l}\text { Prospective } \\
\text { cohort }\end{array}$ & $\begin{array}{l}\text { Exposure: } \\
\text { - ASI-X } \\
\text { Outcome: } \\
\text { - Administrative mortality } \\
\text { data from the Swedish } \\
\text { National Causes of Death } \\
\text { Register }\end{array}$ & $\begin{array}{l}\text { Lifetime history of use for } \\
\text { greater than 6-month } \\
\text { period }\end{array}$ & $\begin{array}{l}\text { Socio-demographic factors } \\
\text { (age, gender, housing status } \\
\text { pre-incarceration, country of } \\
\text { Birth } \\
\text { Psychiatric symptoms during } \\
30 \text { days pre-incarceration or } \\
\text { lifetime } \\
\text { Psychiatric hospitalisation } \\
\text { Previous drug overdose } \\
\text { Substance types used and } \\
\text { substance use history } \\
\text { Crime type }\end{array}$ \\
\hline
\end{tabular}




\begin{tabular}{|c|c|c|c|c|c|c|}
\hline Rognli, 2014 [38] & Sweden & Swedish prisons & $\begin{array}{l}\text { Prospective } \\
\text { cohort }\end{array}$ & $\begin{array}{l}\text { Exposure: } \\
\text { - European version of the } \\
\text { ASI } \\
\text { Outcome: } \\
\text { - Administrative health } \\
\text { data from the Swedish } \\
\text { National Patient Register }\end{array}$ & $\begin{array}{l}\text { Age of first use } \\
\text { Years of use } \\
\text { Days of use in previous } \\
\text { month } \\
\text { Injection the main route of } \\
\text { administration }\end{array}$ & $\begin{array}{l}\text { Socio-demographic factors } \\
\text { (genders, age, education, } \\
\text { employment, homelessness, } \\
\text { country of birth) } \\
\text { Methamphetamine use history } \\
\text { and patterns of use } \\
\text { Psychiatric history } \\
\text { Family psychiatric history and } \\
\text { substance use } \\
\text { Sexual and physical abuse }\end{array}$ \\
\hline Rognli, 2015 [39] & Sweden & $\begin{array}{l}\text { Swedish prisons and } \\
\text { community } \\
\text { corrections }\end{array}$ & $\begin{array}{l}\text { Prospective } \\
\text { cohort }\end{array}$ & $\begin{array}{l}\text { Exposure: } \\
\text { - ASI-X } \\
\text { Outcome: } \\
\text { - Administrative health } \\
\text { data from the Swedish } \\
\text { National Patient Register }\end{array}$ & $\begin{array}{l}\text { Self-reported } \\
\text { amphetamine use as main } \\
\text { drug problem at baseline } \\
\text { interview }\end{array}$ & $\begin{array}{l}\text { Socio-demographic factors } \\
\text { (age, education, pre- } \\
\text { incarceration homelessness, } \\
\text { country of birth) } \\
\text { Substance type } \\
\text { Previous psychiatric } \\
\text { hospitalisation } \\
\text { Non drug-related } \\
\text { hallucinations } \\
\text { Relative with psychiatric or } \\
\text { substance use problems } \\
\text { Sexual or physical abuse }\end{array}$ \\
\hline
\end{tabular}

AOD, alcohol and other drugs, ASI, Addiction Severity Index; ASI-X, Addiction Severity Index (adapted); CES-D, Centre for Epidemiologic Studies Depression Scale. 
Table 3. Study results

\begin{tabular}{|c|c|c|c|c|c|}
\hline Author, date [ref] & $\begin{array}{l}\text { Population/sample and } \\
\text { observation period }\end{array}$ & Mean age \pm SD & $\%$ female & Outcome variables & $\begin{array}{l}\text { Significant relationships between study factors } \\
\text { and outcomes }\end{array}$ \\
\hline Cartier, 2008 [29] & $\begin{array}{l}812 \text { prisoners; } \\
\text { study period not provided }\end{array}$ & 34.1 & 25 & $\begin{array}{l}\text { HIV risk behaviours } \\
\text { (unprotected sex and } \\
\text { injecting using unclean } \\
\text { needles) }\end{array}$ & $\begin{array}{l}\text { Methamphetamine use and risky sex } \\
\text { Methamphetamine use and risky injecting } \\
\text { Risky sex and risky injecting } \\
\text { Age and unprotected sex }\end{array}$ \\
\hline Chiang, 2006 [31] & $\begin{array}{l}794 \text { prisoners; } \\
1999-2004\end{array}$ & $28.4 \pm 7.7$ & 0 & $\begin{array}{l}\text { Recidivism } \\
\text { Recidivism for drug } \\
\text { crimes }\end{array}$ & $\begin{array}{l}\text { Significantly greater odds of recidivism for } \\
\text { participants with positive urinalysis test for } \\
\text { methamphetamine at intake compared to those } \\
\text { testing negative } \\
\text { Heroin users had significantly higher rates of } \\
\text { recidivism than meth users } \\
\text { Heroin users had a shorter survival time to } \\
\text { recidivism than meth users }\end{array}$ \\
\hline Du, 2013 [32] & $\begin{array}{l}1444 \text { adults with criminal } \\
\text { convictions who received AOD } \\
\text { services under a Proposition } 36 \\
\text { program }\end{array}$ & $36.1 \pm 10.0$ & 43 & $\begin{array}{l}\text { Recidivism at } 12 \text { months } \\
\text { follow-up }\end{array}$ & $\begin{array}{l}\text { Younger age predicted recidivism } \\
\text { Recidivism was more likely for female cocaine } \\
\text { compared to methamphetamine users } \\
\text { Screening for drug problems on the ASI predicted } \\
\text { recidivism } \\
\text { Residential treatment was protective against } \\
\text { recidivism compared to methadone therapy } \\
\text { Number of prior arrests predicted recidivism } \\
\text { Number of prior AOD treatment episodes } \\
\text { protected against recidivism }\end{array}$ \\
\hline
\end{tabular}

This article is protected by copyright. All rights reserved. 


\begin{tabular}{|c|c|c|c|c|c|}
\hline Enns, 2017 [33] & $\begin{array}{l}1599 \text { participants (youth and } \\
\text { adult); } \\
\text { September } 2005 \text { - May } 2015\end{array}$ & $\begin{array}{l}\text { Median=39, } \\
\text { IQR: } 26,46\end{array}$ & 34 & Monthly crime cost $\$ \$$ & $\begin{array}{l}\text { Injection methamphetamine use associated with } \\
\text { higher costs than non-injection use } \\
\text { Daily crack use associated with higher crime costs } \\
\text { than no use } \\
\text { Both daily and non-daily methamphetamine use } \\
\text { associated with higher crime costs than no use } \\
\text { Both daily and non-daily polystimulant use } \\
\text { associated with higher crime costs than no use } \\
\text { Any powdered cocaine use associated with higher } \\
\text { crime costs than no use }\end{array}$ \\
\hline Ericsson, 2014 [19] & $\begin{array}{l}1396 \text { justice-involved adults } \\
\text { reporting amphetamine as } \\
\text { primary drug and } \\
\text { amphetamine use in last } 30 \\
\text { days prior to incarceration }\end{array}$ & $37.4 \pm$ & 15 & Death & $\begin{array}{l}\text { Days of sedative use positively predicted death } \\
\text { Days of amphetamine use was protective against } \\
\text { death }\end{array}$ \\
\hline
\end{tabular}

This article is protected by copyright. All rights reserved. 


\begin{tabular}{|c|c|c|c|c|c|}
\hline Håkansson, 2012 [36] & $\begin{array}{l}4152 \text { justice-involved adults; } \\
2001-2006\end{array}$ & $33.2 \pm 9.9$ & 11 & $\begin{array}{l}\text { Return to criminal justice } \\
\text { system (recidivism) }\end{array}$ & $\begin{array}{l}\text { Multiple variables associated with recidivism: } \\
\text { - Male gender } \\
\text { - Homelessness in last } 30 \text { days } \\
\text { - Hospitalisation for psychiatric problem } \\
\text { - Difficulty controlling violent behaviour } \\
\text { - Injection and non-injection use of heroin } \\
\text { - Injection and non-injection use of meth } \\
\text { - Injection and non-injection use of both meth } \\
\text { and heroin concurrently } \\
\text { - Injection use of drugs other than } \\
\text { methamphetamine and heroin } \\
\text { - Higher number of substance types used on last } \\
30 \text { days } \\
\text { Multiple variables protective against recidivism: } \\
\text { - Binge drinking } \\
\text { - Opioid use other than heroin or methadone } \\
\text { - Use of hallucinogenic drugs } \\
\text { - Lower duration of index sentence }\end{array}$ \\
\hline Håkansson, 2013 [37] & $\begin{array}{l}4081 \text { adult prisoners reporting } \\
\text { a substance use problem; } \\
2001-2006\end{array}$ & 33.4 & 10 & Death & $\begin{array}{l}\text { Death positively associated with: } \\
\text { - Older age } \\
\text { - Heroin use } \\
\text { - Drug overdose } \\
\text { Negatively associated with: } \\
\text { - history of depressive symptoms } \\
\text { No association between amphetamine use and } \\
\text { death }\end{array}$ \\
\hline
\end{tabular}

This article is protected by copyright. All rights reserved. 


\begin{tabular}{|c|c|c|c|c|c|}
\hline Rognli, 2014 [38] & $\begin{array}{l}1709 \text { adult prisoners reporting } \\
\text { primary methamphetamine } \\
\text { use; } \\
2001-2010\end{array}$ & $\begin{array}{c}\text { Median=37, } \\
\text { IQR: } 30,44\end{array}$ & 15 & $\begin{array}{l}\text { Future hospitalisation } \\
\text { for: } \\
\text { Primary psychosis } \\
\text { Substance-induced } \\
\text { psychosis }\end{array}$ & $\begin{array}{l}\text { Multiple factors associated with future } \\
\text { hospitalisation for primary psychosis: } \\
\text { - Being born outside of a Nordic country } \\
\text { - Previous psychiatric hospitalisation } \\
\text { - Experienced hallucinations unrelated to drug use } \\
\text { Being homeless in the past month was associated } \\
\text { with future hospitalisation due to substance- } \\
\text { induced psychosis } \\
\text { More years completed at school was protective } \\
\text { against future hospitalisation due to substance- } \\
\text { induced psychosis } \\
\text { Age of onset of amphetamine use not associated } \\
\text { with future hospitalisation due to psychosis } \\
\text { Number of years of amphetamine use not } \\
\text { associated with future hospitalisation due to } \\
\text { psychosis } \\
\text { Amphetamine use in past month not associated } \\
\text { with future hospitalisation due to psychosis }\end{array}$ \\
\hline
\end{tabular}




\begin{tabular}{|c|c|c|c|c|c|}
\hline Rognli, 2015 [39] & $\begin{array}{l}6217 \text { adults either in prison or } \\
\text { under community supervision } \\
\text { - } 1074 \text { reporting no substance } \\
\text { use problems } \\
\text { - } 5143 \text { reporting a substance } \\
\text { use problem; } \\
2001-2006\end{array}$ & $\begin{array}{l}\text { Medians (IQR) for } \\
\text { each substance } \\
\text { category: } \\
\text { No problem: } 28 \text { (23- } \\
\text { 38.5) } \\
\text { Alcohol: } 36 \text { (26-46) } \\
\text { Cannabis: } 24 \text { (21-31) } \\
\text { Amphetamine: } 37 \\
\text { (30-44) } \\
\text { Heroin: } 31 \text { (26-37) } \\
\text { Poly-drug: } 30(24-39)\end{array}$ & 12 & $\begin{array}{l}\text { Future hospitalisation } \\
\text { for: } \\
\text { Primary psychosis } \\
\text { Substance-induced } \\
\text { psychosis }\end{array}$ & $\begin{array}{l}\text { Substance-induced psychosis associated with: } \\
\text { - Homeless in month before incarceration } \\
\text {-Alcohol, cannabis, amphetamine, heroin, poly- } \\
\text { drug use } \\
\text { - Previous psychiatric hospitalisation } \\
\text { - Non drug-related hallucinations } \\
\text { Primary psychosis associated with: } \\
\text { - age (negative) } \\
\text { - cannabis } \\
\text { - Previous psychiatric hospitalisation } \\
\text { - Non drug-related hallucinations }\end{array}$ \\
\hline
\end{tabular}

AOD, alcohol and other drugs; ASI, Addiction Severity Index; IQR, interquartile range 

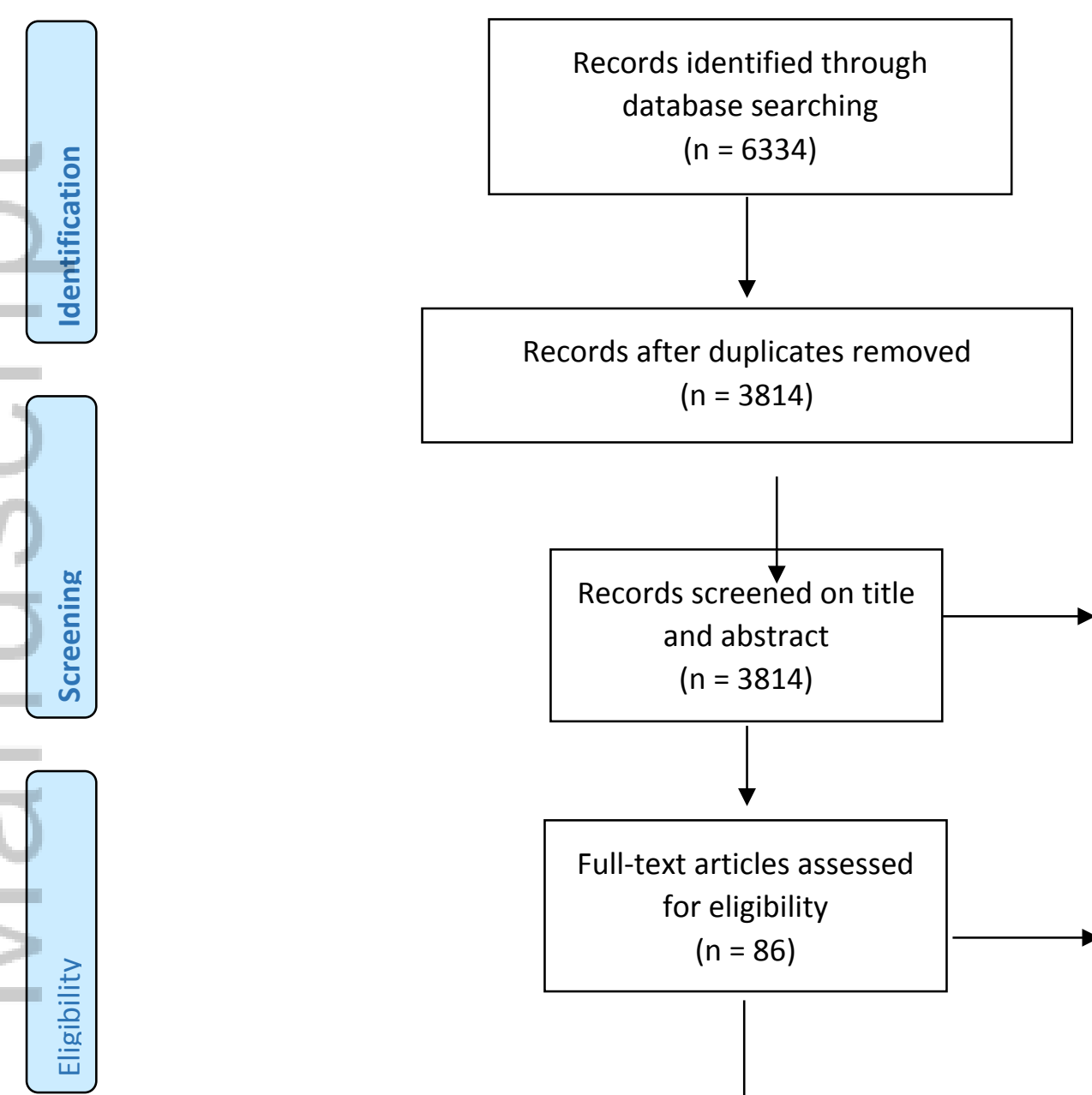

\begin{tabular}{|c|c|}
\hline $\begin{array}{l}\text { Records screened on title } \\
\text { and abstract } \\
(\mathrm{n}=3814)\end{array}$ & $\begin{array}{l}\text { Records excluded }(n=3728) \text { : } \\
\text { Reviews } \\
\text { Grey literature } \\
\text { Pre-CJS methamphetamine use was } \\
\text { not an exposure }\end{array}$ \\
\hline$\downarrow$ & Not longitudinal design \\
\hline $\begin{array}{l}\text { Full-text articles assessed } \\
\text { for eligibility } \\
\qquad(n=86)\end{array}$ & $\begin{array}{l}77 \text { full-text articles excluded: } \\
\text { Not longitudinal design }(n=64)\end{array}$ \\
\hline$\downarrow$ & $\begin{array}{l}\text { service use }(n=6) \\
\text { Methamphetamine use was not an } \\
\text { exposure }(n=4) \\
\text { Methamphetamine use was not } \\
\text { measured }(n=2)\end{array}$ \\
\hline $\begin{array}{l}\text { Studies included in review } \\
\qquad(\mathrm{n}=9)\end{array}$ & $\begin{array}{l}\text { Outcomes did not occur post-CJS } \\
(n=1)\end{array}$ \\
\hline
\end{tabular}

This article is protected by copyright. All rights reserved. 
Figure 1. PRISMA flow diagram of study selection process. CJS, criminal justice system.

This article is protected by copyright. All rights reserved. 


\section{University Library}

\section{- M M N E R VA A gateway to Melbourne's research publications}

Minerva Access is the Institutional Repository of The University of Melbourne

Author/s:

Cumming, C;Kinner, SA;McKetin, R;Li, I;Preen, D

Title:

Methamphetamine use, health and criminal justice system outcomes: A systematic review

Date:

2020-07-01

Citation:

Cumming, C., Kinner, S. A., McKetin, R., Li, I. \& Preen, D. (2020). Methamphetamine use, health and criminal justice system outcomes: A systematic review. DRUG AND ALCOHOL REVIEW, 39 (5), pp.505-518. https://doi.org/10.1111/dar.13062.

Persistent Link:

http://hdl.handle.net/11343/275564 